\title{
CARDIOVASCULAR PATIENT WITH PERMANENT PACEMAKER DUE TO COMPLETE ATRIOVENTRICULAR BLOCK
}

Oladipo D. L., Swanzy-Krah J., Pochinska M. V.

V. N. Karazin Kharkiv National University, Kharkiv, Ukraine

Permanent pacemaker implantation and medical therapy due to complete atrioventricular block and comorbid cardiac pathology are considered at an example of clinical case. Permanent pacemaker solved the problem of AV-block, however, drug therapy due to arterial hypertension, heart failure and dyslipidemia is not canceled and requires modification.

KEY WORDS: complete atrioventricular block, permanent pacemaker

\section{СЕРЦЕВО-СУДИННИЙ ПАЦІЕНТ ІЗ ПОСТІЙНИМ ЕЛЕКТРОКАРДІОСТИМУЛЯТОРОМ З ПРИВОДУ ПОВНОЇ АТРІОВЕНТРИКУЛЯРНОЇ БЛОКАДИ}

Оладіпо Д. Л., Сванзі-Крах Джс., Починська М. В.

Харківський національний університет імені В. Н. Каразіна, м. Харків, Україна

На прикладі клінічного випадку розглянуті можливість імплантації електрокардіостимулятора та медичної терапії з приводу повної атріовентрикулярної блокади і супутньої серцевої патології. Постійний кардіостимулятор вирішив проблему повної атріовентрикулярної блокади, однак лікарська терапія у зв'язку з артеріальною гіпертонією, серцевою недостатністю і дисліпідемією не відміняється і вимагає модифікації.

КЛЮЧОВІ СЛОВА: повна атріовентрикулярна блокада, постійний електрокардіостимулятор

\section{СЕРДЕЧНО-СОСУДИСТЫЙ ПАЦИЕНТ С ПОСТОЯННЫМ ЭЛЕКТРОКАРДИОСТИМУЛЯТОРОМ ПО ПОВОДУ ПОЛНОЙ АТРИОВЕНТРИКУЛЯРНОЙ БЛОКАДЫ}

Оладипо Д. Л., Сванзи-Крах Дже, Починская М. В.

Харьковский национальный университет имени В. Н. Каразина, г. Харьков, Украина

На примере клинического случая рассмотрены возможность имплантации электрокардиостимулятора и медицинской терапии по поводу полной атриовентрикулярной блокады и сопутствующей сердечной патологии. Постоянный кардиостимулятор решил проблему полной атриовентрикулярной блокады, однако лекарственная терапия в связи с артериальной гипертонией, сердечной недостаточностью и дислипидемией не отменяется и требует модификации.

КЛЮЧЕВЫЕ ПЛОВА: полная атриовентрикулярная блокада, постоянный электрокардиостимулятор

\section{INTRODUCTION}

Complete atrioventricular (AV) block occurs in patients with comorbid cardiac pathology [12]. Permanent pacemaker is sole method of treatment of the AV-block, however, it is requiring the control of drug therapy in connection with the change in hemodynamics [3-5].

This clinical case described below shows that pacemaker implantation in patient due to complete $\mathrm{AV}$ block is not canceling drugs support.

\section{CLINICAL CASE}

The patient L., a woman 46 years old was admitted to the cardiology department of the Kharkiv railway clinical hospital No1 of the branch «Center Of Healthcare» of public joint stock company «Ukrainian Railway» on the $6^{\text {th }}$ of September 2017 with complaints of general weakness, dizziness, presyncope, shortness of 
breath during physical activity (walking), disappearing after the rest, light palpitation, headaches in the occipital, parietal, frontal area, pressing character, periodic, arising during excitement, physical exertion.

\section{ANAMNESIS MORBI}

In 2009, she was diagnosed with neurocirculatory dystonia, in 2015 - arterial hypertension $2^{\text {nd }}$ stage $1^{\text {st }}$ grade ( $\max$ blood pressure (BP) $147 / 97 \mathrm{~mm} \mathrm{Hg}$; usual BP $135 / 85 \mathrm{~mm} \mathrm{Hg}$ ), ramipril $2.5 \mathrm{mg}$ was taken from time to time. In 2016 - AV-block second degree (Obits II), in 2017 - complete AV block was diagnosed on a doctor's visit after complains of severe palpitation and electrocardiography (ECG) (see pic. 1). After consulting with the physician and ECG monitoring patient was referred to pacemaker implantation.
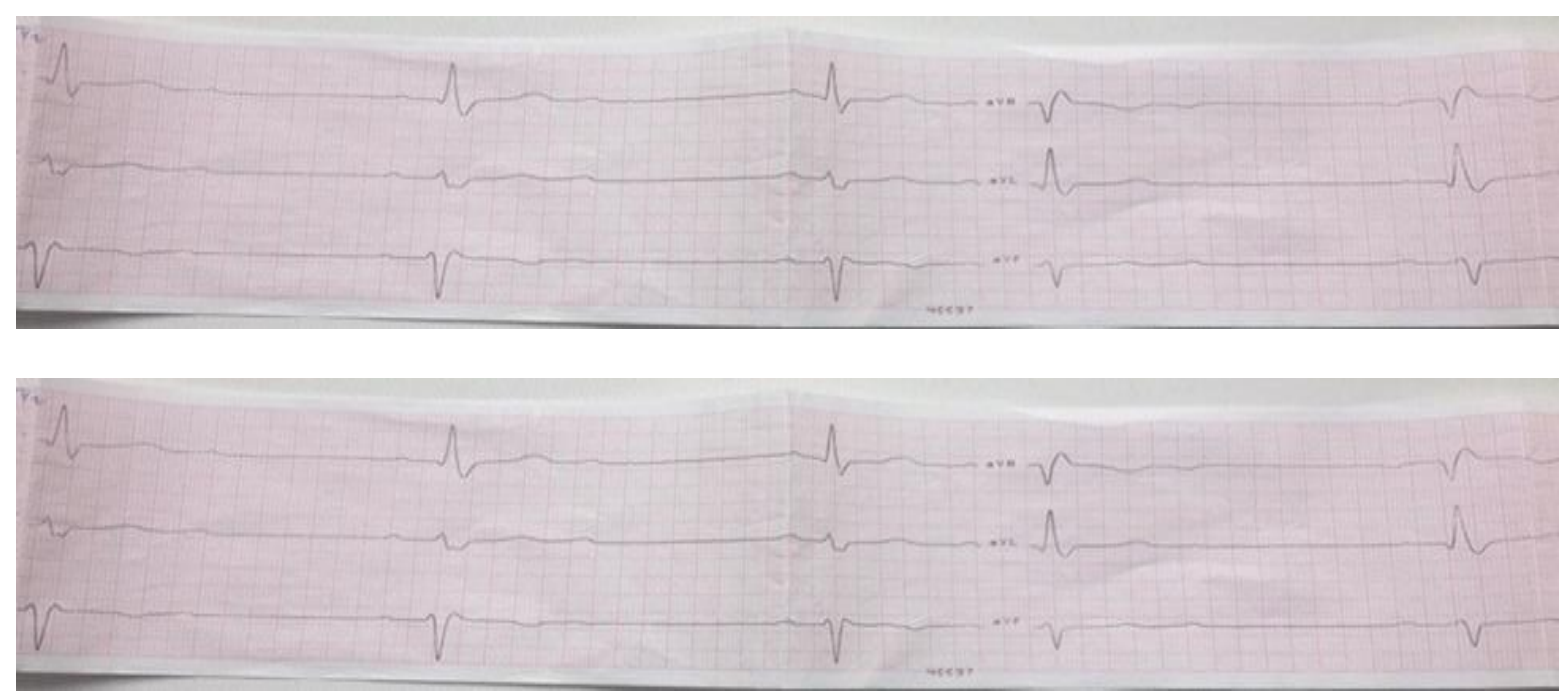

Fig. 1 Complete AV block, heart rate 35 bpm, sinus atrial rhythm, PR interval irregular

\section{ANAMNESIS VITAE}

Childhood infections, injuries, tuberculosis, sexually transmitted diseases were denied by patient. No family history of any endocrine or cardiac disorders. Allergic history is not burdened. Patient denies smoking, do not abuse alcohol.

\section{OBJECTIVE EXAMINATION}

General condition of the patient was satisfactory, consciousness - clear, state severe, body position - active. Emotionally stable and in an optimistic mood. Height = $168 \mathrm{~cm}$, weight $=100 \mathrm{~kg}, \quad \mathrm{BMI}=37.3 \mathrm{~kg} / \mathrm{m}^{2}$. Temperature $-36.7^{\circ} \mathrm{C}$.
Skin is normal colored, without any scars, visible mucous membranes are pale pink and clean. Mucous membranes are pale and wet. Tongue - clear and wet.

Peripheral lymph nodes are not palpable. The thyroid is not palpable, signs of eyelid retraction, periorbital edema, proptosis are absent.

Joints are normal, active and passive movements are not painless.

Respiratory system: the chest is hypersthenic, normal respiratory effort with no use of accessory muscles. Palpation - normal tactile fremitus. Percussion - no clinically significant changes. Auscultation - vesicular breathing, no added sounds. Breathe rate -20 per min. 
Cardiovascular system: no jugular vein distention. Carotid, radial, posterior tibialis, and pedal pulses $2+$ symmetric, no edema. Apex beat localized in the 5th intercostal space, diffuse. Percussion: heart borders extended to the left on $1,5 \mathrm{~cm}$ of midclavicular line. Auscultation: regular S1, S2, normal rhythm, no murmur, rub, or gallop. BP in left hand = $145 / 100 \mathrm{~mm} \mathrm{Hg}, \quad \mathrm{BP}$ in right hand = 140/95 $\mathrm{mm} \mathrm{Hg}, \mathrm{HR}=$ pulse $=35 \mathrm{bpm}$ (before pacing).

Gastrointestinal system: abdomen is soft, painless, symmetrical, no discrepancies of the abdominal muscles, no visible peristalsis, liver edge is smooth, painless, palpated $0.5 \mathrm{~cm}$ below the costal arch, spleen and pancreas are not palpable, stool and diuresis were unremarkable.

Urogenital and sexual systems: Pasternatsky sign is negative. Menopause during 1 year.

\section{LABORATORY AND INSTRUMENTAL TESTS}

Complete blood count, urine and biochemical analysis (07/09/17) were in normal ranges.

Lipid profile $(07 / 09 / 17)$ revealed type IIa dyslipidemia according to Frederickson's phenotype (total cholesterol $=5.29, \mathrm{LDL}=$ 3.75 , atherogenic coefficient $=3.33$ ).

ECG 2 days after pacemaker implantation (09/09/17): complete AV block, sinus atrial rhythm, PR interval regular, RR $>$ PP. Esprit DDD pacemaker: there is $100 \%$ ventricular capture - a QRS complex follows each ventricular pacing spike; no atrial pacing spikes are seen; HR - $65 \mathrm{bpm}$, stimulation threshold $0,75 \mathrm{~V}$, impedance $-350 \mathrm{Om}$ (see pic. 2).

Echocardiography $\quad(06 / 09 / 17)$ : left ventricular hypertrophy (LVH), signs of increasing diastolic stiffness of the LV wall.

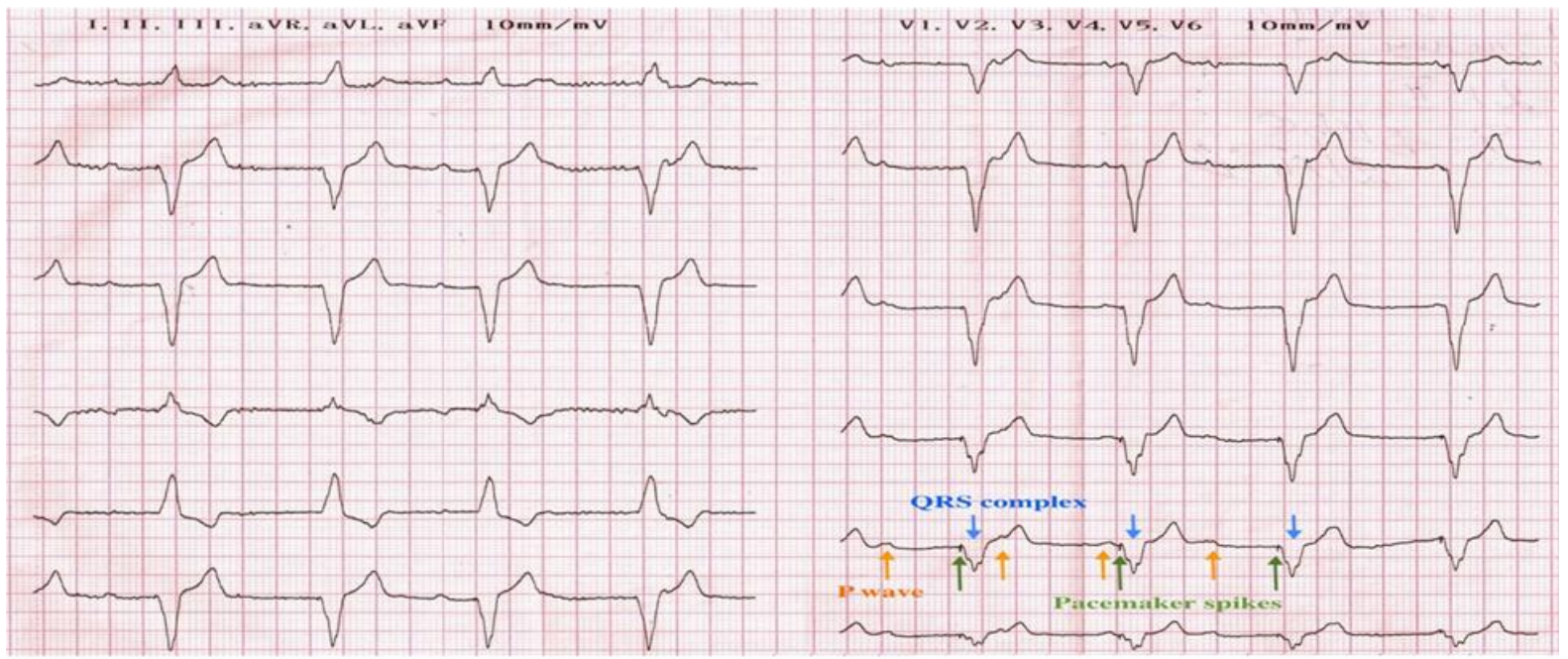

Fig. 2 Condition after cardiac pacemaker implantation (DDDR) due to complete AV block

\section{CLINICAL SYNDROMES}

- Conduction disorder

- Arterial Hypertension

- Heart failure

- Dyslipidemia

- Obesity

\section{CLINICAL DIAGNOSIS}

Main: Ischemic heart disease, condition after cardiac pacemaker implantation (DDDR) due to complete AV block, essential arterial hypertension II $^{\text {nd }}$ stage, $1^{\text {st }}$ grade, hypertensive heart $(\mathrm{LVH})$, heart failure II $\mathrm{B}$, II FC with preserved ejection fraction (EF - 65\%), dyslipidemia II a type (after Fredrickson) and moderate added total $\mathrm{CV}$ risk.

Comorbidity: Obesity II degree.

\section{RECOMMENDATION AND TREATMENT}

Lifestyle modification:

- reducing the weight by $5-10 \%$, $150 \mathrm{~min} /$ week of moderate-intensity exercise (eg, brisk walking) plus flexibility and strength training; 
- eat regular meals and snacks, avoid fasting;

- consume plant-based diet (high in fiber, low calories/glycemic index, and high in phytochemicals/antioxidants);

- use mild cooking techniques instead of high-heat cooking.

Surgical therapy:

Control pacemaker parameters after 1,6 months and 1 year (condition after DDD mode pacing, $9^{\text {th }}$ of September 2017).

Medicament therapy:
- Antiplatelet - Cardiomagnyl $75 \mathrm{mg}$ once daily in the evening;

- Angiotensin receptor blocker Telmisartan $40 \mathrm{mg}$ once daily in the morning;

- Statin - Atorvastatin $40 \mathrm{mg}$ once daily in the evening.

\section{CONCLUSIONS}

Permanent pacemaker solved the problem of AV-block, however, drug therapy due to arterial hypertension, heart failure and dyslipidemia is not canceled and requires modification.

\section{REFERENCES}

1. Socie, Pierre et al. «Frequency Of Recovery From Complete Atrioventricular Block After Cardiac Surgery». The American Journal of Cardiology 120.10 (2017): 1841-1846. Web. 25 Jan. 2018.

2. Liao, Jo-Nan et al. «Long-Term Outcome in Patients Receiving Permanent Pacemaker Implantation for Atrioventricular Block: Comparison of VDD and DDD Pacing». Ed. Heye Zhang. Medicine 95.35 (2016): e4668. PMC. Web. 25 Jan. 2018.

3. Brignole, M. et al. «2013 ESC Guidelines On Cardiac Pacing And Cardiac Resynchronization Therapy: The Task Force On Cardiac Pacing And Resynchronization Therapy Of The European Society Of Cardiology (ESC). Developed In Collaboration With The European Heart Rhythm Association (EHRA) ». Europace 15.8 (2013): 1070-1118. Web. 13 Jan. 2018.

4. Klein, Helmut U., Ilan Goldenberg, and Arthur J. Moss. «Risk Stratification For Implantable Cardioverter Defibrillator Therapy: The Role Of The Wearable Cardioverter-Defibrillator». European Heart Journal 34.29 (2013): 2230-2242. Web. 25 Jan. 2018.

5. Brunacci, Michele et al. «Two Hearts Synchronized Each Other With A DDD Pacemaker». Journal of Cardiovascular Medicine 17 (2016): e239-e240. Web. 25 Jan. 2018. 